\title{
Laparoscopic and bacteriologic evidence of bacterial vaginosis in unexplained infertility
}

\author{
Atef M. Darwish ${ }^{1 *}$, Mahmoud A. AbdelAleem ${ }^{1}$, Micheal N. Agban ${ }^{2}$, Mostafa A. Mohamed $^{1}$
}

\author{
${ }^{1}$ Department of Obstetrics \& Gynecology, Faculty of Medicine, WHU Hospital, Assiut University, Assiut, Egypt \\ ${ }^{2}$ Department of Bacteriology, Faculty of Medicine, WHU Hospital, Assiut University, Assiut, Egypt
}

Received: 16 December 2014

Accepted: 11 January 2015

\section{*Correspondence:}

Dr. Atef M. Darwish,

E-mail: atef_darwish@yahoo.com

Copyright: $(\mathbb{C}$ the author(s), publisher and licensee Medip Academy. This is an open-access article distributed under the terms of the Creative Commons Attribution Non-Commercial License, which permits unrestricted non-commercial use, distribution, and reproduction in any medium, provided the original work is properly cited.

\begin{abstract}
Background: Aim of current study was to estimate the prevalence of Bacterial Vaginosis (BV) among women with Unexplained Infertility (UI) and to describe laparoscopic appearances in positive cases.

Methods: Design: Prospective randomized comparative diagnostic trial. Setting: Tertiary care referral facility and University hospital. Patients: One hundred and fifty women divided into UI study group A (120 cases) and a control group B (30 cases). Intervention(s): Vaginal and endouterine swabs form two subgroups of the UI group (60 cases each) and vaginal swabs from control group (30 cases). All swabs were tested using Amsel's criteria then cultured. Thereafter, UI group (60 cases) was subjected to diagnostic laparoscopy. Main outcome measure(s): the prevalence of BV among women with UI and laparoscopic findings among positive cases.

Results: In the study group, the number of positive cases of BV confirmed by culture was 51 cases (42.5\%) while it was diagnosed in three cases $(10 \%)$ in group $\mathrm{B}(\mathrm{P}=0.0001)$. In group $\mathrm{A}, \mathrm{BV}$ was diagnosed in 24 and 27 infertile cases with periods of infertility less than and more than 3 years respectively and in 39 patients $(32.5 \%)$ with recurrent vaginitis without statistically significant difference. There was an insignificant difference in diagnosis of BV whether the site of sample was the posterior fornix of the vagina or the endometrial cavity. Positive laparoscopic findings were reported in 77 patients $(64.2 \%)$. The most common laparoscopic abnormalities were hyperemic uterus and chronic salpingitis.

Conclusions: BV is frequently implicated in female infertility and it is probably an underestimated cause of UI. There is no extra benefit from using culture instead of Amsel's criteria for the diagnosis of BV. No difference in the site of sample taking in diagnosis of $\mathrm{BV}$ from posterior vaginal fornix or endometrial cavity. Laparoscopy is very beneficial in explaining the effect of $\mathrm{BV}$ on the upper genital tract.
\end{abstract}

Keywords: Bacterial vaginosis (BV), Laparoscopy, Unexplained infertility

\section{INTRODUCTION}

In the past several decades, tremendous advancement in the field of infertility has been made. The development of improved diagnostic methods due to better understanding of physiology of ovulation, advent of ultrasound, endoscopy and other modern equipments have changed the whole approach to this problem. ${ }^{1}$ can be diagnosed after a complete evaluation. ${ }^{2}$ The Practice Committee of the American Society for Reproductive Medicine (ASRM) has published guidelines for a standard infertility evaluation. ${ }^{3}$ UI does not mean there is no physical explanation for the infertility, but rather medical tests have not identified any specific problems. ${ }^{4}$ A quarter of infertility cases cannot be explained because of current tests are not perfect in finding all problems., the problem preventing pregnancy is not covered by the usual 
range of tests for assessing infertility, or causes which are not yet understood by scientists. ${ }^{4}$ Scientific curiosity must take second place to a more pragmatic approach, which takes into account the clinical and financial costs of making a more accurate diagnosis. ${ }^{5}$

Laparoscopy is generally accepted as a good standard for diagnosing tubal pathology or other pelvic reproductive diseases, such as adhesions and endometriosis. Once identified, appropriate surgical treatment can be given, enhancing the chance of spontaneous conception. Furthermore, in cases with poor prognosis, laparoscopy could accelerate the commencement of (IVF), bypassing unnecessary cycles of ovulatory stimulation with or without intrauterine insemination. ${ }^{7}$

Bacterial Vaginosis (BV) is considered the most common cause of vaginitis in sexually active women in their reproductive years. ${ }^{8}$ Nevertheless, the true prevalence and the clinical impact of $\mathrm{BV}$ in infertile women is variable. As such, the aims of this study were to estimate the prevalence of BV among women with UI and to describe laparoscopic appearances in positive cases.

\section{METHODS}

This case-control study was conducted at the women's health Hospital of Assiut University during the period from January 2012 to April 2013, after the approval of research ethics committee and patient's consents. It comprised two groups; the first group A included 120 women in the childbearing period with age range from 20-30 years with primary or secondary UI attending the Infertility outpatient clinic and a second group of 30 fertile women in the childbearing period with age range from 20-30 years as a control group B. Cases in group A and $\mathrm{B}$ were recruited from the infertility and family planning clinics respectively. For group B, all women were not using local methods or intrauterine device at least 3 months before the study. Infertile cases had to fulfill the following criteria according to The Practice Committee of the American Society for Reproductive Medicine (ASRM) ${ }^{3}$ including normal husband semen parameters, patent fallopian tubes as demonstrated by hystrosalpingography (HSG) and normal ovulation utilizing ultrasound or serum progesterone in the second half of the cycle.

The use of antibiotics, other vaginal creams or vaginal douches in the preceding month were considered exclusion criteria for this study. Inclusion criteria of the control group included new clients coming to the family planning outpatient clinic needing a contraceptive method and not complaining of recent or recurrent vaginitis. All patients were subjected to a detailed history taking especially use of vaginal creams or vaginal douches in the preceding month and a thorough pelvic examination. The patient was put in lithotomy position where an unlubricated vaginal Casco speculum was inserted under good light, searching for a grayish white discharge indicative of BV. The 120 infertile patients (group A) were divided into two subgroups according to site of sampling. In the first 60 patients, the sample was obtained from the posterior fornix of the vagina, where a sterile cotton-tipped swab was used. In contrast, the sample in the remaining 60 patients was taken from the uterine cavity (endouterine swab) utilizing a $3 \mathrm{~mm}$ pipette after injection of a few milliltres of $0.9 \%$ saline. In the 30 control patients the sample was taken from the posterior fornix of vagina using a sterile cotton-tipped swab. For all 150 cases, two swabs were taken. The first swab of secretions was fixed by means of flame and was stained with Gram staining to visualize the specific clue cells of BV. The slide was examined under oil immersion microscopy (magnification: x1000) (Olympus CH-20, Japan).

The second swab was rolled on a slide and $10 \%$ potassium hydroxide solution was added to the slide, and then smelt the characteristic fishy odour. Further, the second swab was put into a brain heart broth for 24 hours then prepared for culture. As we previously published, ${ }^{9}$ the diagnosis of BV by Amsel's criteria was confirmed, if three of the four criteria of Amsel were found, which includes a homogeneous greyish white vaginal discharge (color and amount may vary), amine (fishy) odour when $10 \%$ potassium hydroxide solution is added to vaginal secretions (commonly called the "whiff test"), presence of clue cells (greater than 20\%) on microscopy and vaginal $\mathrm{pH}$ greater than 4.5 .

All samples was cultured on brain heart media for identification of gardenerella vaginalis, blood culture for identification of ordinary organisms (Gram positive and Gram negative organisms), and Sabouraud's agar for fungal infection. In all cases, confirmation of isolated organisms by the corresponding chemical reactions was performed. The vaginal \& cervical swabs were immediately transferred to brain heart infusion (BHI) (Himedia - Cat. No. M210) \& vaginalis agar (Himedia Cat. No. M1057) medium was used to detect Gardnerella vaginalis. Detection of Group B Streptococci (GBS) was performed utilizing specific antiserum on the isolated colonies (HiStrep - Latex test kit - Himedia LK0650NO).

The isolated organisms were confirmed biochemically using API system (20A Biomerrieux RES 20300). Antibiogram for isolated microorganisms to detect the proper antibiotic was performed against penicillin, cephalosporins, macrolides, and quinolones (Himedia). Patients with infected cysts received full course of antibiotic according to its antibiogram. Laparoscopy was performed for the 120 infertile cases with stress on any evidence of upper genital tract infection, hyperemia or adhesions.

All patients that were proved to be BV positive were treated with oral metronidazole according to the recommendations of our previous work. ${ }^{10}$ Categorical 
data were described as percentages and compared with chi square and exact Fischer tests. Continuous data were described as mean \pm SD or median (according to data distribution) and compared using $t$ test, Man Whitney test, and ANOVA test with LSD post hock test whenever appropriate. Correlation was used when appropriate. Simple agreement was calculated as a percentage of the number of cases agreed by both methods as positive plus those agreed by both methods as negative and divided by the total number of cases. A probability value ( $\mathrm{P}$ value) $<0.05$ was considered statistically significant. All statistical calculations were performed using computer programs Microsoft excel version 7 (Microsoft Corporation, NY, USA) and SPSS 16 (Statistical Package for the Social Science; SPSS Inc., Chicago).

\section{RESULTS}

This study comprised 120 women with UI (study group) and 30 fertile women (control group) tested for prevalence of BV. In the study group, the number of positive cases of BV confirmed by culture was 51 cases $(42.5 \%)$ while it was diagnosed in only three cases $(10 \%)$ in group $\mathrm{B}(\mathrm{P}=0.0001)$.

In group $\mathrm{A}, \mathrm{BV}$ was positive in 24 and 27 cases with periods of infertility less than and more than three years respectively and in 39 patients $(32.5 \%)$ with history of recurrent vaginitis without statistical significance. Moreover, there was insignificant correlation to the type of infertility or age of women. Likewise, there was an insignificant difference in the diagnosis of BV regardless of sample site (Table 1). As shown in Figure 1 using the Receiver Operator Characteristic (ROC) curve to test Sensitivity and specificity of Amsel's criteria and culture, the area under the curve indicates high specificity of Amsel's criteria and the area above the curve indicates high sensitivity of the culture in diagnosis of BV. In group A, positive laparoscopic findings were reported in 77 patients $(64.2 \%)$. As shown in Table 2, the most common laparoscopic abnormalities were hyperemic uterus and chronic salpingitis.
Table 3 demonstrates a highly significant correlation between confirmed $\mathrm{BV}$ and abnormal laparoscopic findings in UI. Moreover, all abnormal laparoscopic findings except three cases of endometriosis could be explained by positive BV in UI group.

Table 1: Diagnosis of BV by vaginal versus endouterine swab.

\begin{tabular}{|c|c|c|c|c|c|}
\hline \multirow{2}{*}{\multicolumn{2}{|c|}{$\begin{array}{l}\text { Diagnosis of } \\
\text { BV (Amsel's } \\
\text { criteria) }\end{array}$}} & \multicolumn{2}{|c|}{ Site of sample taking } & \multirow[b]{2}{*}{ Total } & \multirow{2}{*}{$\begin{array}{l}P \\
\text { value }\end{array}$} \\
\hline & & Endouterine & Vaginal & & \\
\hline \multirow[b]{2}{*}{$+\mathrm{ve}$} & No & 28 & 23 & 51 & \multirow{6}{*}{0.853} \\
\hline & $\begin{array}{l}\% \text { of } \\
\text { total }\end{array}$ & $23.30 \%$ & $19.20 \%$ & $42.50 \%$ & \\
\hline \multirow[b]{2}{*}{$-\mathrm{ve}$} & No & 32 & 37 & 69 & \\
\hline & $\begin{array}{l}\% \text { of } \\
\text { total }\end{array}$ & $26.70 \%$ & $30.80 \%$ & $57.50 \%$ & \\
\hline \multirow[b]{2}{*}{ Total } & No & 60 & 60 & 120 & \\
\hline & $\begin{array}{l}\% \text { of } \\
\text { total }\end{array}$ & $50.00 \%$ & $50.00 \%$ & $100.00 \%$ & \\
\hline
\end{tabular}

Table 2: Correlation between positive cases of BV and laparoscopic findings in UI group.

\begin{tabular}{|c|c|c|c|c|c|}
\hline \multirow{2}{*}{\multicolumn{2}{|c|}{$\begin{array}{l}\text { Diagnosis of } \\
\text { BV (Amsel's } \\
\text { criteria) }\end{array}$}} & \multicolumn{2}{|c|}{$\begin{array}{l}\text { laparoscopic } \\
\text { manifestations } \\
\text { of upper GTI* }\end{array}$} & \multirow[t]{2}{*}{ Total } & \multirow[t]{2}{*}{$\begin{array}{l}P \\
\text { value }\end{array}$} \\
\hline & & $+v e$ & -ve & & \\
\hline \multirow[b]{2}{*}{$+v e$} & Count & 50 & 1 & 51 & \multirow{6}{*}{0.0001} \\
\hline & $\begin{array}{l}\% \text { of } \\
\text { Total }\end{array}$ & $41.7 \%$ & $0.8 \%$ & $42.5 \%$ & \\
\hline \multirow[b]{2}{*}{-ve } & Count & 27 & 42 & 69 & \\
\hline & $\begin{array}{l}\% \text { of } \\
\text { Total }\end{array}$ & $22.5 \%$ & $35 \%$ & $57.5 \%$ & \\
\hline \multirow[b]{2}{*}{ Total } & Count & 77 & 43 & 120 & \\
\hline & $\begin{array}{l}\% \text { of } \\
\text { Total }\end{array}$ & $64.2 \%$ & $35.8 \%$ & $100.0 \%$ & \\
\hline
\end{tabular}

*GTI: genital tract infection

Table 3: Relation between positive cases of bacterieal vaginosis and laparoscopic findings.

\begin{tabular}{llllllll}
$\begin{array}{l}\text { Diagnosis of } \\
\text { bacterial } \\
\text { vaginosis } \\
\text { (Amsel's criteria) }\end{array}$ & $\begin{array}{l}\text { Chronic } \\
\text { salpingitis }\end{array}$ & Endometriosis & $\begin{array}{l}\text { Fine } \\
\text { adhesions }\end{array}$ & $\begin{array}{l}\text { Hyperemic } \\
\text { uterus }\end{array}$ & $\begin{array}{l}\text { Massive } \\
\text { adhesions }\end{array}$ & Normal & Total \\
+ve & Count & 13 & 3 & 8 & 14 & 12 & 1 \\
\hline & $\%$ of total & $10.8 \%$ & $2.5 \%$ & $6.7 \%$ & $11.7 \%$ & $10.0 \%$ & $0.8 \%$ \\
\hline \multirow{2}{*}{-ve } & Count & 7 & 5 & 5 & 8 & 2 & 42 \\
\hline \multirow{2}{*}{ Total } & \%of total & $5.8 \%$ & $4.2 \%$ & $4.2 \%$ & $6.7 \%$ & $1.7 \%$ & $35.0 \%$ \\
\hline
\end{tabular}




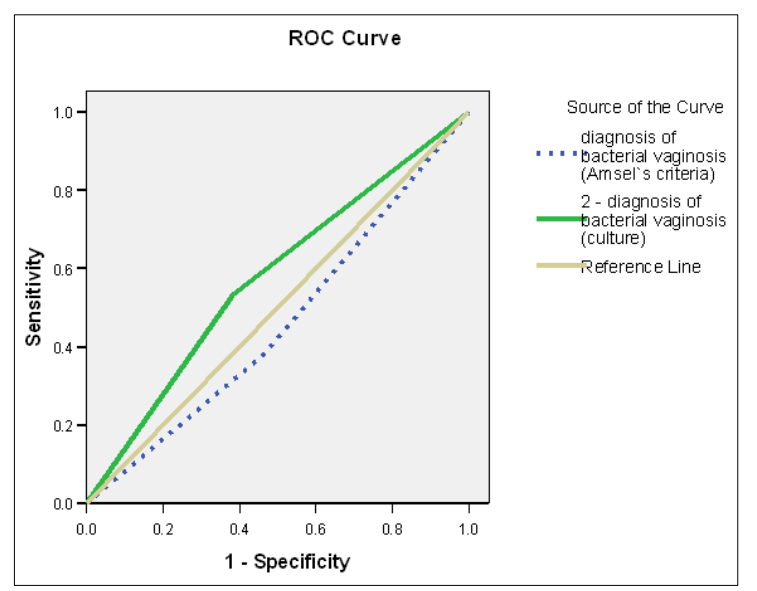

Figure 1: Diagnostic indices of Amsel's criteria versus culture for the diagnosis of $\mathrm{BV}$.

\section{DISCUSSION}

UI is a continuous challenge for all gynecologists worldwide. Possible etiologies for UI may include hostile cervical mucus, ${ }^{11}$ subtle ovulatory dysfunction, ${ }^{12}$ luteal phase defect, ${ }^{13}$ impaired fertilizing ability of oocytes specially when associated with raised LH levels, hyperprolactinemia, ${ }^{14}$ sperm dysfunction and antisperm antibodies, ${ }^{15}$ endometrial steroid receptor defects, ${ }^{16}$ some genetic, ${ }^{17}$ psychological. ${ }^{18}$ or immunological causes. ${ }^{19}$ Prospective studies appear to have clearly demonstrated the substantial importance of even minimal endometriosis, which has been shown to be associated with impaired fertilization ability of oocyte and presumably impaired follicular function. Changes in the intraperitoneal environment leading to an inflammatory process in the absence of visible abnormalities have been suggested as being causal in some cases of unexplained infertility. ${ }^{15}$ Occult infections are important explanation of UI particularly in patients who are unable to clearly give a history to explain a source for their tubal adhesions. BV infection was reported as a significant association with infertility and its proper treatment had led to pregnancy, emphasizing the value and clinical implication of its screening and treatment. ${ }^{20}$ It is hypothesized that immunity to infection might be correlated to sperm rejection in women with positive BV, leading to infertility. ${ }^{21}$ In contrast, low prevalence of BV $(4.2 \%)$ was reported in a population of women undergoing in-vitro fertilization/embryo transfer (IVFET) where 331 infertile women were selected. ${ }^{22}$ Variable results of many studies on the prevalence of BV among infertile women particularly UI were one of the main indications to construct our study.

In this study, we found that the prevalence of $\mathrm{BV}$ in women with UI was $42.5 \%$, while in the fertile women (the control group) it was $10 \%(\mathrm{P}$ value $=0.0001)$. These results were similar to others who reported BV in $45.5 \%$ versus $15.5 \%$ of the infertile and the control groups respectively. ${ }^{20}$ On the other hand, BV was reported in only $18.9 \%$ of women with UI. ${ }^{23}$ The same team reported rates of $12-15 \%$ in those with endometriosis and male factor infertility and $33-36 \%$ in those with anovulation and tubal infertility respectively. Women with tubal factor were two to three times more likely to have BV than women with other types of infertility. ${ }^{23}$ These findings highlight the importance of searching for $\mathrm{BV}$ in cases with tubal factor of infertility.

Our study reported no significant difference in the results of samples taken from the posterior fornix of vagina and those taken from the endometrial cavity ( $\mathrm{P}$ value $=$ 0.853). However, detection of clue cells in the endometrial cavity of women with UI demonstrates the possibility of ascending route of BV to the upper genital tract.

Regarding the role of culture for diagnosis of $\mathrm{BV}$, we reported in $45.8 \%$ and $42.5 \%$ in culture and using Amsel's criteria respectively without any significant difference. Our results showed that culture was a sensitive but not a specific method for diagnosing oBV compared to Amsel's criteria which is demonstrated by ROC curve. Likewise, culture was unhelpful for the diagnosis of $\mathrm{BV}$ due to an imbalance of the normal organisms, without any pathogens necessarily being present. $^{24}$

The sensitivity and specificity of vaginal cultures for anaerobic bacteria (Bacteroides and Peptostroptococcus) and Mycoplasma hominis were reported in one study. ${ }^{24}$ They found that the presence of these organisms was a more specific indicator of $\mathrm{BV}$ than the presence of $\mathrm{G}$. vaginalis but their detection had inadequate sensitivity. ${ }^{24}$ Another group of anaerobic bacteria, Mobiluncus species, which is highly associated with $\mathrm{BV}$, was very difficult to recover with culture methods. ${ }^{26}$

Whether BV should be considered a cause or an association with infertility was studied in a big cohort study of 874 infertile women and 382 asymptomatic fertile women. ${ }^{27}$ The prevalence of BV was significantly higher in infertile than fertile women $(45.5 \%$ vs. $15.4 \%)$. Its prevalence in UI was $37.4 \%$ which is more or less similar to our results $(42.5 \%)$. In a recent systematic review and a meta-analysis, ${ }^{28}$ it was concluded that all studies on infertility in relation to BV included had a cross-sectional design and, therefore, do not allow for causal inferences. Our study and others ${ }^{27}$ would support the concept of definite correlation between UI and BV.

In a previous study, 114 women with UI were examined laparoscopically. Laparoscopy revealed pelvic pathology in 95 patients. Endometriosis, pelvic adhesions and tubal disease were observed and treated in 72, 46 and 24 patients, respectively. They could treat 72 patients of them, and 35 of them conceived using their own tubes. However they concluded that diagnostic laparoscopy should be strongly considered in UI work-up, and tubal efficacy should not be underestimated. ${ }^{7}$ In our study, positive laparoscopic findings were reported in 77 patients $(64.2 \%)$. We found that laparoscopy can reveal 
upper genital tract pathology in 50\% of positive cases with $\mathrm{BV}$ and it was negative in $35 \%$ of negative cases with $\mathrm{BV}(\mathrm{P}=0.0001)$. There was a significant correlation between the positive cases of $\mathrm{BV}$ and the pathological lesions diagnosed by laparoscopy especially hyperemic uterus, chronic salpingitis and massive adhesions ( $\mathrm{P}=$ 0.0001). Subsequently, we recommend meticulous screening of women with these abnormal laparoscopic findings for possibility of hidden intrauterine infections. In addition to Chlamydia trachomatis and Neiserria gonorrhoea infections which are on the rise, BV should be put in mind of infertility specialists.

From our study, BV is highly implicated in female infertility and it is probably an underestimated cause of UI. There is no extra benefit from using culture instead of Amsel's criteria for the diagnosis of BV. No difference in the site of sample taking in diagnosis of $\mathrm{BV}$ from posterior vaginal fornix or endometrial cavity. Laparoscopy is very beneficial in explaining the effect of $\mathrm{BV}$ on the upper genital tract. Further studies are required to test the impact of proper treating $\mathrm{BV}$ on subsequent fertility in case of UI.

\section{Funding: No funding sources}

Conflict of interest: None declared

Ethical approval: The study was approved by the research ethics committee

\section{REFERENCES}

1. Ray A, Shah A, Gudi A, Homburg R. Unexplained infertility: an update and review of practice. Reprod Biomed Online. 2012;24:591-602.

2. Smith S, Pfiefer SM, Collins J. Diagnosis and management of female infertility. JAMA. 2003;290:17.

3. The Practice Committee of the American Society for Reproductive Medicine. Optimal evaluation of the infertile female. Fertil Steril. 2006;86(5 suppl):S2647.

4. Cahill DJ, Wardle PG. Management of infertility. Br Med J. 2002;325:28-32.

5. Randolph JF. Unexplained infertility. Clin Obstet Gynecol. 2000;43:897-901.

6. Siristatidis C, Bhattacharya S. Unexplained infertility: does it really exist? Does it matter? Hum Reprod. 2007;22(8):2084-7.

7. Bonneau C, Chanelles O, Sifer C, Poncelet C. Use of laparoscopy in unexplained infertility. Eur J Obstet Gynecol Reprod Biol. 2012;163(1):57-61.

8. Casari E, Ferrario A, Morenghi E, Montanelli E. Gardenerella, Trichomonas vaginalis, Candida, chlamedia trachomatis, mycoplasma hominis and Ureaplasma urealiticum in the genital discharge of symptomatic fertile \& asymptomatic infertile women. New Microbiologica. 2010;33:69-76.

9. Darwish AM, Makarem MH, Alnashar EM, Hamadeh SM. Screening for bacterial vaginosis in high-risk pregnancy: the experience of a developing country. Acta Obstet Gynecol Scand. 2005;;84(5):483-5.

10. Darwish AM, Elnshar EM, Hamadeh SM, Makarem $\mathrm{MH}$. Treatment options of bacterial vaginosis in high-risk patients of preterm labor and premature rupture of membranes. J Obstet Gynecol Res. 2007;33(6):781-7.

11. Querlen D. Fertility after conization. Rev Fr Gynecol Obstet. 1991;86(2):81-2.

12. Paulson RJ. Unexplained infertility. In: Paulson RJ, eds. Mishell's Textbook of Infertility, Contraception and Reproductive Endocrine. 4th ed. US: WileyBlackwell; 1997: 743-753.

13. Speroff L, Glass RH, Kase NG. Etiologies of unexplained Infertility. In: Speroff L, Glass RH, Kase NG, eds. Clinical Gynecology Endocrine and Infertility. 5th ed. Baltimore, London: Williams \& Wilkins; 2004: 24.

14. Balasch J, Fabregues F, Creus M, Casamitjana R, Peurto B, Vanrell JA. Recombinant human follicular stimulating hormone for ovulation induction in polycystic ovary syndrome: a prospective, randomized trial of two starting doses in a chronic low dose step up protocol. J Assist Reprod Genet. 2000;17(10):561-5.

15. Cahill DJ, Wardle PG. Management of infertility. Br Med J. 2002;325:28-32.

16. Schild RL, Knobloch C, Dorn C, Fimmers R, Van derv en H, Hansmann M. Endometrial receptivity in an in vitro fertilization program as assessed by spiral artery blood flow. Fertil Steril. 2001;75:361-6.

17. Li H, Chen S, Xing F. Expression of HOXA10 gene in human endometrium and its relationship with unexplained infertility. Chinese J Obstet Gynecol. 2002;37(1):30-2.

18. Collins JA Burrows EA, Willam AR. The prognosis for live birth among untreated infertile couples. Fertil Steril. 1995;64:22-8.

19. Choudhury SR, Knapp LA. Human reproductive failure: Immunological factors. Hum Reprod Update. 2001;7(2):113-34.

20. Rasheed M. Salah, Abdelmonem M. Allam, Amin M. Magdy, Abeer Sh. Mohamed. Bacterial vaginosis and infertility: cause or association? Eur J Obstet Gynecol Reprod Biol. 2013;167:59-63.

21. Mania-Pramanik J, Kerkar SC, Salvi VS. Bacterial vaginosis: a cause of infertility? Int J STD \& AIDS. 2009;20:778-81.

22. Spandorfer SD, Neuer A, Giraldo PC, Rosenwaks Z, Witkin SS. Relationship of abnormal vaginal flora, proinflammatory cytokines and idiopathic infertility in women undergoing IVF. $\mathrm{J}$ Reprod Med. 2001;46:806-10.

23. Janet D. Wilson, Susan G. Ralph, Anthony J. Rutherford. Rates of bacterial vaginosis in women undergoing in vitro fertilization for different types of infertility. BJOG: Int $\mathrm{J}$ Obstet Gynecol. 2002;109:714-7. 
24. Lamont RF. Bacterial vaginosis. In: Lamont RF, eds. Year book of obstetrics and gynecology. 1st ed. Saint Louis: Mosby-Year Book; 1998: 149, 154-158.

25. Krohn MA, Hiller SL. Comparison of methods for diagnosing bacterial vaginosis among pregnant women. J Clin Microbiol. 1989;27:1266-71.

26. Hiller SL, Krohn MA, Nugent RP. Characteristics of the vaginal flora patterns assessment by gram stain among pregnant women. Am J Obstet Gynecol. 1992;166:938-49.

27. Salah RM, Allam AM, Magdy AM, Mohamed ASH. Bacterial vaginosis and infertility: cause or association? Eur J Obstet Gynecol Reprod Biol. 2013 Mar;167(1):59-63.

28. van Oostrum N, De Sutter P, Meys J, Verstraelen H. Risks associated with bacterial vaginosis in infertility patients: a systematic review and meta-analysis. Hum Reprod. 2013 Jul;28(7):1809-15.

DOI: $10.5455 / 2320-1770 . i j r \operatorname{cog} 20150231$

Cite this article as: Darwish AM, AbdelAleem MA, Agban MN, Mohamed MA. Laparoscopic and bacteriologic evidence of bacterial vaginosis in unexplained infertility. Int J Reprod Contracept Obstet Gynecol 2015;4:173-8. 